\title{
Relationship between E-recruitment Adoption and Good Governance Practices in Nigerian Public Sector: An Empirical Study
}

\author{
Ahmad Sanusi (Corresponding Author) \\ College of Law, Government and International Studies, \\ Universiti Utara Malaysia \\ 06010 Sintok Kedah, Malaysia \\ sanusicomputer@yahoo.com
}

\begin{abstract}
Ahmad Martadha Mohamed
Associate Professor: College of Law, Government and International Studies, Universiti Utara Malaysia

06010 Sintok Kedah, Malaysia

martadha@uum.edu.my
\end{abstract}

Received: June 21, 2012 Accepted: November 27, 2012 DOI: 10.5296/jpag.v2i4.1965

\begin{abstract}
The universal quest for good governance forces different countries to adopt e-recruitment as recruiting strategy in hiring their teeming workforce in line with global best practices. As part of public service reform Nigerian government encourage public sector organisations to jettison conventional recruitment method in favour of electronic recruitment for transparency, accessibility and efficiency in recruitment exercises. This study empirically investigates the relationship between e-recruitment adoption and good governance practices in Nigerian public service. The study Modified Technology Acceptance Model (TAM) to analyse the response generated from 326 survey respondents. The findings indicated that e-recruitment adoption is yet to provide good governance. In the overall, this study offer important insight and recommended that government agencies involved should put effective machinery in motion in order to enrich and improve good governance practices in e-recruitment in Nigerian public sector.
\end{abstract}

Keywords: Recruitment, E-recruitment, Good Governance, Reforms and Public Sector 


\section{Introduction}

The present level of globalization warrants different countries to reform their public service structures for efficiency and improved public service delivery. Part of these reforms is the introduction of electronic recruitment strategy which allows job seekers to apply online. In Nigeria, public service reforms started before it was granted independence and self governance from the British colonial administrators. Most of the public service reforms were primarily geared towards transformation on administrative structures and building solid foundations in line with British imperial hegemony. During that period, attention was given to administrative procedures, institutionalization of work ethics and value orientation. The policy makers naively assumed that a mere reorganisation of administrative structure and procedure would work magic by increasing productivity. Such reasoning is very naive, because even a causal observer of governmental day-to-day activities knows that the so-called structural problems are not just structural and procedural in nature but socio-cultural and value oriented in approach. It is pertinent to note that public service reforms need to be fully implemented in Nigeria because of long time devastation by previous military administrations. Such changes recorded little progress through the introduction of modern and innovative administrative frameworks in an attempt to develop the capacity of administrative institutions in such a way that assigned duties and responsibilities can be effectively and efficiently executed (Sanusi \& Ahmad, 2012).

The hallmark of reforms in recruitment process in contemporary societies is the introduction of e-government which essentially refers to as the use of public bodies of information and communication technologies to deliver information and services to internal and external customers and organisations, elected representatives and other stakeholders in order to complement, replace or improve traditional delivery system (Humphrey et al., 2003). In contemporary public service reforms in Nigeria, the central issue is the transition from the use of traditional administrative techniques to modern tools in government operations. Government introduced new information and communication technology into its business in order to achieve efficient operations, better quality services and easy access to information and other online services (Kraemer \& Zhu, 2005).

Recruiting few qualified candidates to fill an existing job opening in the midst of large number of applicants is one of the tasking roles of human resource managers. In the public service, the proper management of men, money, machinery, methods and materials can only be achieved if qualified personnel are recruited to administer managerial and non managerial positions. Previous studies showed that improper recruitment and poor placement of right kind person in a right kind job at a right time negated the principles of good governance and hence jeopardized the organisational zeal to attain its stated goals.

\section{Literature Review}

Previous studies revealed that Technology Acceptance Model (TAM) proved to be successful empirically in predicting whether the system is accepted or rejected by the users and it offer cost effective tool that can be use to evaluate the system design and its life cycle (Morris \& Dillion, 1997). It was described as the most generic and economic model that could be used 
to study both initial and continued technology adoption and it provide additional information required in understanding technology adoption. Davis (1989) defines perceived usefulness as the degree to which a person believes that using particular system would enhance his job performance. This means people are more likely to use a system that they believed is important to them and can help them to perform their duty diligently and effectively. Davis (1989) describes perceived ease of use as the degree to which a person believes that using a particular technology will be free of effort. Users believe that a given application is useful but they may at the same time, believe that the technology is too hard to use and that the performance benefits of usage are outweighed by the effort of using the application.

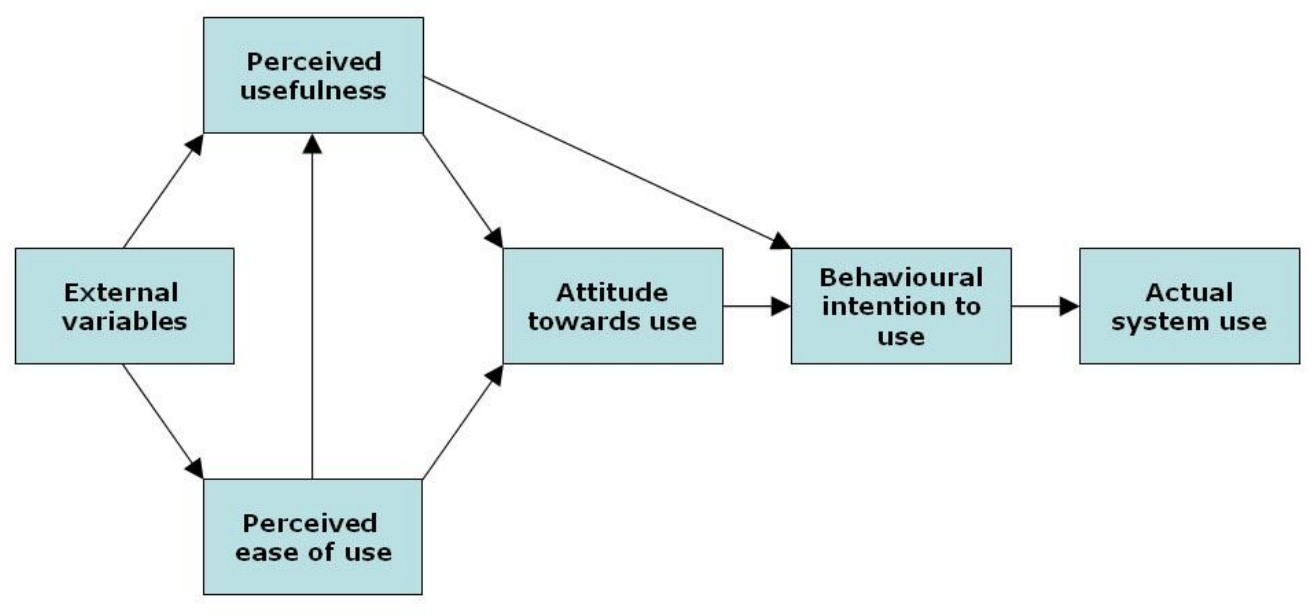

Figure 1: Original Technology Acceptance Model (TAM)

Davis (1989) asserted that the external variables can emanate from different angles like organisational structure, system features, user characteristics and the likes. However, he never clearly stated the sub-factors of the system features that may affect the adoption level as well as the usage of the system. In a related development further investigation connected to the antecedent factors of perceived ease of use and perceived usefulness were successfully conducted by Hubona and Kennick (1996). They conducted their research using two TAM models: One with external variables of age, employment status, and educational level while the other one is without external variables. The results showed external variables or antecedent factors have significant relation with the usage frequency. They concluded that for integrating new technologies effectively into the organisation the introduction of the influence of external variables in TAM would help explain the exact system usage and adoption.

In a study conducted by Pavon (2006) on the factors influencing the adoption of the internet for job-seeking in South Africa about 220 questionnaires were collected and analysed. The result showed that perceived usefulness and perceived ease of use are the most reliable predictors of adoption of the internet for job-seeking, whereas trust and effort expectancy have little value in determining intention to use the internet for that purpose. The result further reveal that even though the internet is making a growing impact, traditional channels for job-seeking such as newspapers are still an important tool for job seeking and recruitment. 


\section{Macrothink}

It also confirmed that the internet broad reach changes the scope for job seekers and recruiting organisations potentially stimulating greater worker mobility with cybercafés contributing towards narrowing the digital divide by making the internet available to people who cannot afford it. The study has some loopholes which includes its inability to widen it respondents thereby concentrating only on IT applicants. Being it a study of technology adoption it is appropriate to use Technology Acceptance Model (TAM) because it provide an explanation of the determinants of adoption by tracing the impact of external factors on internal beliefs, attitudes and intentions (Davis, 1989) and it is a valuable tool for predicting attitudes, proper conduct and usage from beliefs and external variables (Al-Gahtani \& King, 1999).

Tong (2009) conducted study on e-recruitment technology adoption in Malaysia using the validated modified Technology Acceptance Model (TAM) without the construct as the core research framework and identifying Perceived Privacy Risk (PPR), Performance Expectancy (PE), Application-Specific Self-Efficacy (ASSE), and Perceived Stress (PS) as key external variables that form the research model. The study used 262 participants using snowball non-probability sampling method through identifying few key determinants to technology adoption. The result from weak evidence of behavioural intention indicates that e-recruitment has not replaced the conventional recruitment methods. The study was criticised because it used snowball non-probability sampling method targeted only younger respondents with first degree qualifications conducted within Malaysian urban setting, and uses self-report scales which might inflate correlations through common methods variance (Fusilier \& Durlabhji, 2005).

Szajna (1994) conducted a research using the two key concept of TAM and found that perceived usefulness and perceived ease of use were able to predict the intent to use; self reported usage, and attitude toward use. The empirical results reveal that TAM can be tested in various domains, tools and the users. These results showed the predictive, robust and validity of perceived ease of use and perceived usefulness as initially proposed by Davis, (1986).

\section{Research Model}

The proposed research model was adapted from research conducted on e-government adoption (Colesca \& Liliana, 2009) using Technology Acceptance Model constructs like Perceived Usefulness (PU), Perceived Ease of Use (PEOU), Perceived Trust (PT), Perceived Quality (PQ), User Satisfaction (US), Demographic Variables like Age, Gender, Occupation, Education Level, Income, Prior Internet Experience and finally E-Government Adoption.

The research model depict of independent variables: perceived usefulness, perceived ease of use, perceived trust and perceived quality, the mediating variable e-recruitment adoption and the dependent variable good governance practices. These constructs and their items are tested and validated empirically. The research model is provided below: 


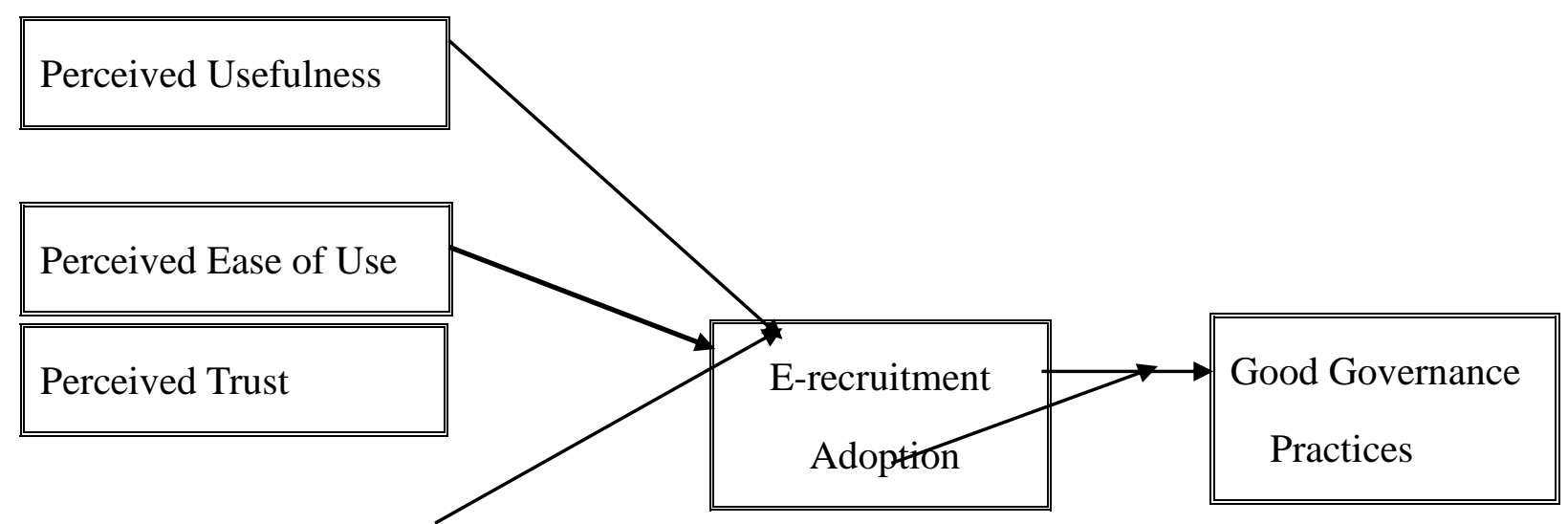

Figure 2: Research Model

Perceived Quality

In this study constructs from the adapted model were dropped and new constructs of good governance practice and e-recruitment adoption were added to new framework because Technology Acceptance Model (TAM) can be extended by using domain-specific constructs when used with newer technologies (Serenko \& Bontis, 2004).

\section{Hypotheses Development}

The model was built on Modified Technology Acceptance Model (TAM) and the governance theory. This study has the following hypotheses.

H1: Perceived usefulness positively relates to good governance practices

$\mathrm{H} 2$ : $\quad$ Perceived ease of use positively relates to good governance practices

H3: Perceived trust positively relates to good governance practices

H4: Perceived quality positively relates to good governance practices

H5: Perceived usefulness positively influence e-recruitment adoption

H6: Perceived ease of use positively influences e-recruitment adoption

H7: Perceived trust positively influence e-recruitment adoption

H8: Perceived quality positively influence e-recruitment adoption

H9: E-recruitment adoption positively associated with good governance practices

\section{Methodology}

Survey method was used because it has the lowest comparative cost compared to other 
methods of quantitative data collecting method (Sekaran, 2003). Quantitative research is based on the assumption that anything that exists does so in quantities and can be measured numerically. Quantitative research methodology is appropriate where quantifiable measures of variables of interest are possible, where hypotheses can be formulated and tested, and inferences drawn from samples to population (Adamu, 2006). Among the major reasons for using quantitative method in research is because of its power of generalisation, predictive capability and full explanations of causal relationship (Tashakkori \& Teddlie, 1998). The data collected in this study originated from the primary sources. Questionnaires were designed to answer questions which are related to the tested variables. The main instruments of each variable were adapted from previous studies but with modifications on the arrangement and direction of relationships. The items adapted in this study were based on their high reliability of their Cronbach's Alpha Coefficient in previous empirical studies. Five items were used to measure Perceived Usefulness (PU) adapted from Davis (1989) Venkatesh \& Brown (2001) and Tong (2009). Also five items were used to measure Perceived Ease of Use (PEOU) adapted from studies conducted by Davis (1989), Venkatesh \& Brown (2001) and Yu et al. (2005). The third variable Perceived Trust (PT) was measured using five items adapted from Wang et al. (2003), Chan \& Lu (2004) and Colesca (2008). Perceived Quality (PQ) was measured using five items adapted from Parasuraman et al. (1988), Yang (2005) and Colesca and Liliana (2009). This study used five items to measure E-Recruitment Adoption (EA) adapted from Colesca (2008) and Tong (2009). As depict in research model five items were used to measure Good Governance Practices (GGP) as adapted from Lynn (2001), Ali and Sentosa (2008) and Kettani et al. (2009). All the items used in this study possessed their own meanings and conceptualisation as they relates to this study.

The population of the study is 15000 as such 375 samples are targeted to fully participate in this study as suggested by Krejcie and Morgan (1970). Therefore, due to the anticipated low response about 600 questionnaires were randomly distributed to the target population. Stratified proportionate random sampling was used in this study because it gives room for every stratum of the sub population to be represented exactly in proportion to its size (Mohammed, 2008). The population of public servants and applicants are heterogeneous as such they are stratified and randomly selected proportionately to form homogeneity for easy selection of the sample. After the conduct of pilot study to test the reliability of measuring instruments and preliminary data screening about 326 usable questionnaires were used to analyse the responses.

\section{Pilot Study}

In the pilot study, about $80(n=80)$ returned questionnaires were used to determine the reliability of measuring instruments. Reliability is essentially about consistency in measures, and it allows for estimation of errors. In ensuring reliability, Cronbach's alpha was used to explain how well the items in a set are positively correlated to each other. The results from the pilot study are presented in Table 1. 
Table 1: Reliability Measurement in the Pilot Study

\begin{tabular}{|l|c|r|l|}
\hline & Variables & No. of Items & Cronbach's Alpha \\
\hline 1. & PU & 5 & .716 \\
\hline 2. & PEOU & 5 & .735 \\
\hline 3. & PT & 5 & .745 \\
\hline 4. & PQ & 5 & .710 \\
\hline 5. & EA & 5 & .723 \\
\hline 6. & GGP & 5 & .872 \\
\hline
\end{tabular}

The results from the pilot study revealed that Perceived Usefulness (PU) is .716, Perceived Ease of Use (PEOU) .735, Perceived Trust (PT) .745, Perceived Quality (PQ) .710, E-Recruitment Adoption (EA) .723 and Good Governance Practices (GGP) .872. Therefore the Cronbach's alpha of all the items ranges from .710-.872

\section{Demographic Profile of Respondents}

Table 2: Demographic Profile of Respondents in the Main Study

\begin{tabular}{|l|l|l|l|}
\hline Demographic & Items & Respondents & Percentage \\
\hline \multirow{2}{*}{ Age } & $25-30$ & 123 & 37.7 \\
\cline { 2 - 4 } & $31-35$ & 157 & 48.2 \\
\cline { 2 - 4 } & $36-40$ & 20 & 6.1 \\
\cline { 2 - 4 } & $41-45$ & 16 & 4.9 \\
\cline { 2 - 4 } & $46-$ Above & 10 & 3.0 \\
\hline \multirow{2}{*}{ Gender } & Male & 233 & 71.5 \\
\cline { 2 - 4 } & Female & 93 & 28.5 \\
\hline Education & Diploma/ NCE & 35 & 10.7 \\
\hline
\end{tabular}




\begin{tabular}{|c|c|c|c|}
\hline \multirow[t]{5}{*}{ Level } & Degree/HND & 201 & 61.7 \\
\hline & $\begin{array}{l}\text { PG/Advance } \\
\text { Diplomas }\end{array}$ & 49 & 15.0 \\
\hline & $\begin{array}{l}\text { Masters } \\
\text { Degree/MPhil }\end{array}$ & 38 & 11.7 \\
\hline & $\mathrm{PhD}$ & 1 & .3 \\
\hline & Others & 2 & .6 \\
\hline \multirow[t]{3}{*}{ Employment } & Public Servants & 126 & 38.7 \\
\hline & Applicants & 162 & 49.7 \\
\hline & Students & 38 & 11.7 \\
\hline \multirow{4}{*}{$\begin{array}{l}\text { Internet } \\
\text { Experience }\end{array}$} & Below 1 Year & 133 & 34.7 \\
\hline & 1-5 Years & 132 & 40.5 \\
\hline & 6-10 Years & 79 & 24.2 \\
\hline & 10 and Above & 2 & .6 \\
\hline
\end{tabular}

Out of 326 respondents, about $123(37.7 \%)$ are within the age bracket of 25-30 years, 157 $(48.2 \%)$ are within the age range of 31-35 years, about $20(6.1 \%)$ respondents are within the ages of 36-40 years while 16 (4.9\%) of respondents fall within 41-46 years while respondents from 46 years and above are 10 constituting 3.0\%. On the gender 233 representing $71.0 \%$ are males while females are about 93 constituting $28.5 \%$ of the total respondents. Analysis of educational qualification of respondents revealed that about $35(10.7 \%)$ are Diploma and National Certificate of Education (NCE) holders, 201 (61.7\%) are Degree and Higher National Diploma holders, 49 (15.0\%) are Postgraduate and Advance Diploma holders, 38 $(11.7 \%)$ are Masters Degree and MPhil holders and only one PhD holder constituting about $(.3 \%)$ of the respondents. On employment status $126(38.7 \%)$ are public servants, $162(49.7 \%)$ are applicants while $38(11.7 \%)$ are final year students of the university. Prior internet experience of the respondents showed about 113 (34.7\%) possessed below 1 year internet experiences, $132(40.5 \%)$, from $1-5$ years 79 (24.2\%) have internet experience from 6-10 years while only $2(.6 \%)$ of the respondents gained internet experiences above 10 years. 


\section{1) Macrothink}

\section{Reliability Measurement}

Previously in the pilot study, all the measuring items are appropriate enough to measure what they are supposed to measure with positive level of reliability. The same method was adopted to test the reliability (Cronbach's Alpha), sampling adequacy (Kaiser-Meyer-Olkin-KMO) and appropriateness of the research model through Bartlett's test of sphericity. At the initial stage of quantitative data analysis, the first step is to test the measuring items. The main reason for conducting reliability test is to ascertain how suitable a set of items can fit into some sources of variance which is measured using Cronbach's Alpha Coefficient. The minimum Cronbach's Alpha Coefficient should range from 0.50 to 0.70 ; Hair et al. (2006) recommended a minimum of .050; Churchill (1999) recommended 0.60 while both Nunnally (1979) and Venkatesh (2000) recommended for a minimum Cronbach's Alpha Coefficient of 0.70 .

Table 3: Reliability Measurement in the Main Study

\begin{tabular}{|l|l|r|l|l|}
\hline & Constructs & No. of Items & \multicolumn{2}{|l|}{$\begin{array}{l}\text { Cronbach's } \\
\text { Alpha }\end{array}$} \\
\hline 1. & PU & 5 & .801 & .827 \\
\hline 2. & PEOU & 5 & .721 & .735 \\
\hline 3. & PT & 5 & .786 & .790 \\
\hline 4. & PQ & 5 & .803 & .765 \\
\hline 5. & EA & 5 & .811 & .802 \\
\hline 6. & GGP & 5 & .880 & .849 \\
\hline
\end{tabular}

In order to test the hypotheses of this study we conducted multiple regression analysis. In Table 3 we summarised the findings from the tested hypothesis and the result revealed that about seven hypotheses were supported while two were not supported. 


\section{Al Macrothink}

Table 4: Summary of Results from Tested Hypotheses

\begin{tabular}{|c|c|c|}
\hline & Path of Relationship & Results \\
\hline $\mathrm{H} 1$ & PU GGP & NOT SUPPORTED \\
\hline $\mathrm{H} 2$ & $\mathrm{PEOU} \longrightarrow \mathrm{GGP}$ & SUPPORTED \\
\hline $\mathrm{H} 3$ & $\mathrm{PT} \longrightarrow \mathrm{GGP}$ & SUPPORTED \\
\hline $\mathrm{H} 4$ & $\mathrm{PQ} \longrightarrow \mathrm{GGP}$ & SUPPORTED \\
\hline H5 & $\mathrm{PU} \quad \mathrm{EA}$ & SUPPORTED \\
\hline H6 & $\mathrm{PEOU} \longrightarrow \mathrm{EA}$ & NOT SUPPORTED \\
\hline $\mathrm{H} 7$ & $\mathrm{PT} \longrightarrow \mathrm{EA}$ & SUPPORTED \\
\hline H8 & $\mathrm{PQ} \longrightarrow \mathrm{EA}$ & SUPPORTED \\
\hline H9 & $\mathrm{EA} \longrightarrow \mathrm{GGP}$ & SUPPORTED \\
\hline
\end{tabular}

Results from the tested hypotheses indicated that about seven hypotheses are supported while two hypotheses are not supported. It is in tandem with previous studies (Amin, 2007; Colesca \& Liliana, 2009; Davis, 1989; Fusilier \& Durlabhji, 2005; Ramayah \& Fernando, 2009; Tong, 2009).

\section{Findings and Discussions}

Results from regression analysis found that perceived usefulness is not significantly related to good governance practices $(\beta=0.027, p=0.621)$. Though no previous studies were conducted to test the relationship between perceived usefulness and good governance practices but related studies like Brown (2002) confirmed that perceived usefulness is negatively related to usage of information system $(\beta=0.04, p=.793)$ and there is no significant relationship between PU and citizens intention to use e-government services. The result from multiple regression analysis revealed that perceived ease of use is significantly related with good governance $(\beta=.132, p=0.025)$. Phatthana and Mat (2010) revealed that perceived ease of use was found to be positively related to e-purchase intention $(\beta=0.39, p=0.03)$. This result is consistent with (Davis, 1989; Venkatesh \& Davis, 2000; Venkatesh et al., 2003; Pikkarainen et al., 2004; Ramayah \& Fernando, 2009; Amin, 2007). The result from the analysis found that PQ significantly related to good governance $(\beta=.147, p=0.005)$ which is in line with Colesca and Liliana (2009) where perceived quality is statistically significant to e-government $(\beta=0.34, p=0.000)$. The significant relationship between perceived quality and good governance practices imply that perceived quality of e-recruitment adoption can fully 
explain good governance practices. This studies found that there is no significant relationship between PEOU and e-recruitment adoption $(\beta=.090, p=.070)$ that the insignificant relationship between perceived ease of use and e-recruitment adoption denotes that an easier system does not necessarily create potency for adopting e-recruitment as recruitment strategy in Nigerian public service. In tandem with this result Tong (2009) discovered that perceived ease of use is not positively related to e-recruitment adoption. The result also vindicated previous studies in which PU is more important predictor than PEOU in determining whether or not to adopt technology (Igbaria et al., 1989; Venkatesh, 2000; Fusilier \& Durlabhji, 2005).

\section{Implications for Further Studies}

Further research should pay more attention to testing the mediating effect of e-recruitment adoption between PU, PEOU, PT, and PQ with GGP. Of great relevance also, is the need for putting additional constructs in the independent variables so that robust and more validated results could be obtained. Additionally, using qualitative or mixed methods in the future will help in getting in-depth information through face to face interview with the stakeholders involved.

\section{Conclusions}

This study provides overarching picture and empirical on the relationship between e-recruitment adoption and good governance practices using public service as the focus. The results from the findings provided support for the key theoretical propositions. Evidently, this study answered all the research questions through testing 9 hypotheses within which 7 are supported and 2 are not supported. The research findings could be use to provide suitable solution and the way forward in enhancing good governance practices in e-recruitment in both developed and developing countries. The purpose of jettisoning conventional recruitment method in favour of e-recruitment in public sector organisations is to ensure good governance in the conduct of the exercise (Odumeru, 2009) call for this study to empirically investigate the applicability of such good governance indicators. With the present quest for good governance in government daily operations, this study will be useful to policy makers and public sector practitioners on the ways to improve transparency, accountability, responsiveness, accessibility and efficiency in e-recruitment in private and public sectors.

\section{References}

Adamu A.U. (2006). Qualitative, quantitative and mixed research methodologies. Readings in Social Science Research, (1): pp.59-73.

Al-Gahtani, S. (2001). The applicability of TAM outside North America: An empirical test in the United Kingdom. Information Resources Management Journal, (3): pp.37-46.

Ali, J., and Sentosa, I. (2008). The mediating effect of good governance on the relationship between managerial roles and personal development, Journal of US-CHINA Public Administration, 5(6): pp.1-15.

Amin, H. (2007). Internet banking adoption among young intellectuals. Journal of Internet Banking and Commerce, 12(3): pp.1-13. 
Brown, I.T.J. (2002). Individual and technological factors affecting perceived ease of use of web-based learning technologies in developing country. EJISDC, 9(5): pp.1-15.

Chan, S., and Lu, M. (2004). Understanding internet banking adoption and use behaviour: A Hong Kong perspective. Journal of Global Information Management, 12(3):pp.21-43.

Churchill, G.A. (1999). Marketing research: Methodological foundations. Dryden Press: Fourth Worth.

Colesca, S.E. and Liliana, D. (2008). Adoption and use of e-government services: The case of Romania. Journal of Applied Research and Technology, 6(3): pp.204-217.

Colesca, S.E. and Liliana, D. (2009). E-government adoption in Romania. International Journal of Business, Economics, Finance and Management Science, 1(2): pp.121- 125.

Davis, F.D. (1986). A technology acceptance model for empirically testing new user information system: Theory and result. Sloan School of Management Massachusetts, USA.

Davis, F.D. (1989). Perceived ease of use and perceived usefulness, and the user acceptance in information technology. Management Information System Quarterly, 13(3): pp.319- 340.

Fusilier, M., and Durlabhji, S. (2005). An exploration of student internet use in India. Campus-Wide Information Systems, 22(4): pp.233-246.

Hubona, G.S., and Kennick, E. (1996). The influence of external variables on information technology usage behaviour. In the Proceedings of the 29th Annual Hawaii International Conference on System Sciences, pp.166-75.

Humphrey, P., O’Donnell, O., and Timonen, V. (2003). E-Government and the decentralisation of service delivery. CPMR, Discussion Paper 25, Dublin.

Igbaria, M., Pavri, F., and Huff, S. (1989). Microcomputer applications: An empirical look at the usage. Information and Management Journal, 16(1): pp.189-196.

Kettani, D., Gorstein, M., and El Mahdi, A. (2009). Good governance and e-government: Applying a formal outcome analysis methodology in developing world context. International Journal for Electronic Governance, pp.22-54.

Kraemer, K.L. and Zhu, K., (2005). Post-adoption variation in usage and value of e-business by organisation: Cross-Country evidence from retail industry. Information Systems Research, 16(1): pp.61-84.

Krejcie, R.V, and Morgan, D.W (1970). Determining sample Size for research activities. Educational and Psychological Measurement, (30): pp.607-610.

Lynn, L. (2001). Improving governance: A new logic of empirical research. Washington D.C: Georgetown University Press.

Mohammed, I.Z. (2008). Sampling in social science research. Readings in social science research. Adamu Joji Publishers, Kano, Nigeria. 
Morris, M.G. and Dillon, A. (1997). How user perceptions influence software use. IEEE Software, 14: pp.58-64.

Nunnally, J. (1979). Psychometric theory. (2nd ed.). McGraw-Hill, New York.

Odumeru, J.A. (2009). Diffusion of online recruitment technology in Nigeria. www.wbiconpro.com/415odumerupdf, 1-12, Accessed April 13th, 2012.

Parasuraman, A., Zeithaml, V.A., and Berry, L.L. (1988). SERVQUAL: A multiple item scale for measuring consumer perceptions of service quality, Journal of Retailing, 64(1): pp.12-40.

Pavon, F. (2006). Factor influencing the adoption of the internet for job-seeking in South Africa: Technical report. University of Cape Town, South Africa. pp.1-70.

Phatthana, W., and Mat, N.K.N. (2010). The application of technology acceptance model (TAM) on health tourism e-purchase intention predictors in Thailand. International Conference on Business and Economic Research (ICABEC, 2010), pp.196-199.

Pikkarainen, T., Pikkarainen, K., Karjaluato, H., and Pahnila, S. (2004). Consumer acceptance of online banking: An extension of the technology acceptance model. Internet Research, 14(3): pp.224-235.

Ramayah, T., and Fernando, Y. (2009). Factors influencing intention to use e- government services among citizens in Malaysia'. International Journal of Information Management, 29(6): pp.458-475.

Sanusi, A., and Ahmad, M.M. (2011). Mainstreaming good governance practices in e-recruitment in Nigerian public service. International Conference on Management (ICM), Penang, Malaysia $13^{\text {th }}-16^{\text {th }}$ June, 2011.

Sanusi, A., and Ahmad, M.M. (2011). Public sector reforms and e-recruitment in Nigeria: Will good governance count. European Journal of Social Sciences, 26(4): pp.616-625.

Sanusi, A., and Ahmad, M.M. 2012. Good governance as yardstick to measure e-recruitment in Nigerian public service. US-CHINA Journal of Public Administration, 9(1): pp.1-7.

Sanusi, A., and Ahmad, M.M. (2012). Nigeria's global good governance ranking and its effect on public service reforms. International Conference on Arts, Social Science and Technology (ICAST), Penang, Malaysia, $3^{\text {rd }}-5^{\text {th }}$ March, 2012.

Sekaran, U. (2003). Research methods for business. (4th ed.). Hoboken, NJ: John Wiley and Sons.

Serenko, A., and Bontis, N. (2004). A model of user adoption of mobile portals. Journal of Electronic Commerce, 4(1): pp.69-98.

Szajna, B. (1994). Software evaluation and choice: Predictive validation of the technology acceptance model. Management Information System Quarterly, 18(3): pp.319-324.

Tashakkori, A., and Teddlie, C. (1998). Mixed methodology: Combining qualitative and quantitative approaches. Thousand Oaks, CA: Sage Publications. 


\section{Macrothink}

Journal of Public Administration and Governance ISSN 2161-7104 2012, Vol. 2, No. 4

Tong, D.Y.K. (2009). A study of e-recruitment technology adoption in Malaysia. Industrial Management and Data System, 109(2): pp.281-300.

Venkatesh, V. (2000). Determinants of perceived ease of use: Integrating control, intrinsic motivation, and emotion into the technology acceptance Model. Information System Research, 11(4): pp.342-365.

Wang, Y.S., Wang, Y.M., Lin, H.H., and Tang, T.I. (2003). Determinants of user acceptance of internet banking: An empirical study. International Journal of Service Industry Management, 1(5): pp.501-519.

Yang, K.C.C. (2005). Exploring factors affecting the adoption of mobile commerce in Singapore. Telematics and Informatics Journal, 22: pp.257-277.

Yu, J., Ha, I., Choi, M., and Rho, J. (2005). Extending the technology acceptance model for t-commerce. Information Management Journal, (42): pp.962-976. 